Lifshitz, N., and C. C. St. Clair. 2019. Iridescent coloration of Tree Swallows relates to environmental metal pollution. Avian Conservation and Ecology 14(2):7. https://doi.org/10.5751/ACE-01411-140207

Copyright (C) 2019 by the author(s). Published here under license by the Resilience Alliance.

Research Paper

\title{
Iridescent coloration of Tree Swallows relates to environmental metal pollution
}

\author{
Natalia Lifshitz ${ }^{1}$ and Colleen Cassady St. Clair ${ }^{1}$ \\ ${ }^{1}$ University of Alberta
}

\begin{abstract}
Ornamental coloration in birds has been identified as a powerful, noninvasive tool for identifying exposure to metal pollution. Despite this potential, few studies have examined the effects of metals on iridescent coloration or assessed related impacts on bird fitness. Iridescent coloration is likely to be sensitive to metal pollution because it is already known to affect melanin production and this form of coloration is produced when light is refracted through layers of keratin and melanin inside feather barbules. In this study, we measured variation in plumage coloration, health (via oxidative stress), and reproductive success (via number of young fledged) of Tree Swallows (Tachycineta bicolor) nesting adjacent to water bodies containing different levels of metal pollution. Plumage hue shifted from bluer to greener and feather brightness was greater, where concentrations of copper and zinc were higher. Both patterns would be expected from changes in the microstructure of the feathers. Unexpectedly, increasing exposure to these metals correlated with increased apparent health (lower oxidative stress) in female swallows, but not males. Number of young fledged decreased slightly with exposure to metals but did not vary with the color of parents. Our results suggest the relationships between ornamental color, including iridescence, and fitness metrics are complex and much more work will be needed before color of iridescent feathers can provide a proactive, noninvasive, and effective diagnostic tool for detecting subtle effects of pollution on birds.
\end{abstract}

\section{La coloration iridescente des hirondelles bicolores est liée à la pollution de l'environnement par les métaux}

RÉSUMÉ. La coloration ornementale des oiseaux a été identifiée comme un outil puissant et non-invasif permettant de connaître leur exposition à la pollution par des métaux. Malgré ce potentiel, peu d'études ont examiné les effets des métaux sur la coloration iridescente ou évalué les impacts connexes sur la santé des oiseaux. La coloration iridescente est probablement sensible à la pollution par les métaux car on sait déjà qu'elle affecte la production de mélanine et que cette forme de coloration est produite par les reflets de la lumière dans les couches de kératine et de mélanine qui se trouvent dans les barbules des plumes. Dans cette étude, nous avons mesuré les variations de la coloration du plumage, la santé (via le stress lié à l'oxydation) et le succès de la reproduction (via le nombre de jeunes oiseaux) chez l'hirondelle bicolore (Tachycineta bicolor) nichant à proximité de plans d'eau affectés par différents niveaux de pollution par les métaux. La nuance du plumage variait du bleu au vert et l'éclat des plumes était plus important dans les endroits où les concentrations de cuivre et de zinc étaient les plus élevées. Ces deux tendances sont des conséquences normales de l'évolution de la microstructure des plumes. Étonnamment, l'exposition croissante à ces métaux était liée à une amélioration apparente de la santé (baisse du stress oxydant) chez les hirondelles femelles, mais pas chez les mâles. Le nombre d'oisillons prenant leur envol diminuait légèrement sous l'effet de l'exposition aux métaux, mais ne variait pas selon la couleur des parents. Nos résultats suggèrent que les relations entre la couleur ornementale, y compris l'iridescence, et les mesures de santé sont complexes et que de nombreuses autres études seront nécessaires pour que la couleur des plumes iridescentes fournisse un outil proactif, non-invasif et efficace permettant de détecter les effets subtils de la pollution sur les oiseaux.

Key Words: conservation; early indicator; iridescence; metal pollution; ornamental coloration; oxidative stress; tree swallow

\section{INTRODUCTION}

Elemental metals are naturally found in the environment (Bradl 2005) and some are a critical part in the diet of vertebrates (Bogden and Klevay 2000, Valko et al. 2005). However, environmental concentrations of many metals have increased because of anthropogenic activities (Azimi et al. 2005, Roux and Marra 2007), reaching levels that become harmful instead of helpful for exposed individuals (Ercal et al. 2001). Normally, industrial areas are most affected by this kind of pollution (Hsu et al. 2006), but metal levels are high in urban areas as well, raising concerns for the health of both humans and wildlife that reside there (Roux and Marra 2007, Wei and Yang 2010). It has become common to estimate potential detrimental effects of many environmental contaminants by studying their effects on sentinel wildlife species (Rabinowitz et al. 2005), including several species of wild birds (e.g., Burger and Gochfeld 2004, Smits and Fernie 2013).

Known negative effects of metal pollution on birds include depressed immune function (Snoeijs et al. 2004), increased oxidative stress (Koivula and Eeva 2010), and impaired reproduction (Brasso and Cristol 2008). Determining these effects has usually required invasive methods, such as blood sampling to

Address of Correspondent: Natalia Lifshitz, Department of Biological Sciences, University of Alberta, Edmonton, Alberta, Canada,

lifshitz@ualberta.ca 
measure health metrics (e.g., Koivula et al. 2011), injection of immune-stimulating agents to assess individual responsiveness (e. g., Cruz-Martínez et al. 2015), and sacrifice of eggs and/or individuals to sample tissues for presence of metals (e.g., Hoffman and Heinz 1998, Snoeijs et al. 2004). Such invasive techniques are often not justifiable on ethical grounds unless pollution levels are already believed to be significant, which may not occur until environmental degradation is difficult to reverse and population declines have already begun (Vasseur and Cossu-Leguille 2006). A familiar example of this sequence is provided by the historic egg-shell thinning of raptorial birds, which was suspected (Carson 1962) decades before it was confirmed and corrected (Freedman 1989).

Ornamental coloration of birds provides a reliable and noninvasive alternative to these invasive approaches, because it reveals physical condition, in turn indicating early effects of environmental pollution (reviewed in Lifshitz and St. Clair 2016). Because production and maintenance of colored ornaments is costly and directly linked to individual condition, these traits are extremely sensitive to environmental quality relative to traits maintained by natural selection (Møller and Pomiankowski 1993, Hill 1995), and reveal the sum of all environmental pressures. This link means that a localized reduction in ornament coloration could signal the first subtle decline in environmental quality, occurring when there is still time to identify and reverse the source of degradation (Hill 1995). Several studies have already explored the link between bird coloration and metal pollution by focusing on carotenoid- and melanin-based coloration (e.g., Eeva et al. 1998, Dauwe and Eens 2008, Geens et al. 2009, Giraudeau et al. 2015), but the effects of metals on structural coloration, especially iridescence, remain largely unexplored (McCarty and Secord 2000, White and Cristol 2014, Chatelain et al. 2017).

One possible reason for the relative lack of attention linking metal pollution to iridescent coloration is the complexity of the underlying physical and chemical mechanisms leading to its production. Iridescent coloration is produced by the refraction of light through specifically arranged nanostructure of the feather, which consists of layers of keratin and melanin (Prum 2006). Each of these layers is responsible for different characteristics of the color produced; hue (or color) is determined by the thickness of the keratin cortex of barbules, such that birds with thicker barbule cortexes have plumage that reflects light maximally at longer wavelengths (Doucet et al. 2006). Color saturation and UV reflectance are determined by the concentration and type of melanin granules deposited under the keratin cortex, such that birds with greater densities of melanin in their barbules have plumage that looks more saturated and reflects proportionally more in UV wavelengths (Doucet et al. 2006, Maia et al. 2009). Environmental metals could potentially affect the production of iridescent colors through several, nonexclusive mechanisms. First, some metals can directly influence the biochemical pathway of melanin production, either by promoting it (Prota 1993, Jawor and Breitwisch 2003) or preventing it (Lerner 1952), and can also alter production of the keratin-based structure of the feather (Crewther et al. 1965). Second, metals have endocrine-disruptive properties (Iavicoli et al. 2009), which could cause changes to the production of sexual hormones, also known to regulate melanin production (Bókony et al. 2008). Additionally, metals could alter feathers indirectly by degrading the condition of individuals, which could, in turn, increase the production of corticosterone, a stress hormone known to prevent melanogenesis (Slominski et al. 2004, Roulin et al. 2008), although recent research found no effects of corticosterone levels on the feather color of female Tree Swallows (Tachycineta bicolor; Sarpong et al. 2019). Lowered condition caused by exposure to metals can also deplete the resources individuals allocate to production of the keratin-based feather structure (DesRochers et al. 2009), or even by reducing the time birds spend preening and caring for their feathers (Chatelain et al. 2016).

Here, we explored the effects of metal pollution at four sites surrounded by a different degree of urbanization on iridescent plumage coloration of Tree Swallows. Tree Swallows are assumed to reveal nearby water pollution because they regularly forage within a few hundred meters of their nest sites (Mengelkoch et al. 2004) on emergent insects from which many pollutants, including metals, bioaccumulate (Bishop et al. 1995, McCarty 2001, Custer 2011). They readily nest in boxes that can be installed adjacent to sites of interest, exhibit high site fidelity (Winkler et al. 2004), have low rates of breeding dispersal, i.e., movements between successive breeding sites (Shutler and Clark 2003), and produce altricial young that they feed for at least 20 days. These features make Tree Swallows particularly effective as bioindicators of pollution (McCarty 2001, Custer 2011, Smits and Fernie 2013), but past studies have emphasized metrics from swallow blood (e.g., Gentes et al. 2007a), eggs (e.g., Custer et al. 2005), or tissue (e.g., Custer et al. 2006). Almost nothing is known about the effects of pollutants on coloration of Tree Swallows, but pollution from polychlorinated biphenyls (PCBs) caused earlier acquisition of adult plumage in females (McCarty and Secord 2000), suggesting a disruption in the endocrine system that affected color production.

We expected iridescent blue plumage of Tree Swallows to be particularly revealing of environmental stressors during breeding for three reasons. First, structural colors may be costly to produce; iridescent plumage of Cowbirds (Molothrus ater) was affected by nutritional stress during feather production (McGraw et al. 2002). Similarly, Anna's Hummingbirds (Calypte anna) receiving a highprotein diet showed higher chroma and hue of iridescent crown feathers, although iridescent gorget feathers were unaffected (Meadows et al. 2012). Second, the blue coloration of Tree Swallows is an ornamental trait under mutual sexual selection in males and females, which increases the likelihood of being an honest indicator of condition (sensu Hamilton and Zuk 1982). Both sexes appear to prefer brighter partners (Bitton et al. 2008) and bluer plumage correlates with higher reproductive success of females (Bitton et al. 2007, 2008, Bentz and Siefferman 2013). Third, environmental effects on coloration of Tree Swallows likely occur via conditions on natal and breeding territories. Tree Swallows begin molting new feathers on their breeding range following each breeding season (Stutchbury and Rohwer 1990). Adding this to the fact that they show high rates of nest-site fidelity (Shutler and Clark 2003), adult plumage in a given year has been assumed to reveal and relate to pollution levels of the same breeding sites in the previous year (McCarty and Secord 2000). Additionally, breeding season stressors can have carry-over effects that extend through migration (Catry et al. 2013, Legagneux et al. 2013, Schultner et al. 2014) potentially to 
completion of molt, although stressors, including pollution, may also occur during migration to affect feather color.

The objective of this study was to determine if higher concentrations of environmental metals correlated with variation in coloration of Tree Swallow feathers, thereby demonstrating the potential for this ornamental trait of Tree Swallows, already a recognized bioindicator species (Custer 2011), to be a noninvasive indicator of metal pollution. To verify the expected negative effects of pollution on bird health that could be reflected in coloration, we had two subsidiary objectives to determine whether increased metal concentrations reduced the health of breeding adults, as measured via oxidative stress, and reduced reproductive success, as measured by the number of young fledged. Oxidative stress refers to the ratio in blood between oxidized and reduced glutathione (GSSG:GSH), the latter serving as the main intracellular antioxidant, such that higher ratio values signal poorer health (Isaksson et al. 2005). In addition to assessing the presumed causal effects of metal pollution on each of these three types of variables, we also explored the relationship between color of parents and number of young fledged, as a proxy of reproductive success.

\section{METHODS}

\section{Study area}

The study was conducted in the summer of 2016. Based on existing information about heavy metal concentrations in water (City of St. Albert 2012; A. Liu, personal communication) and on surrounding habitat and land use type, we chose four sites along apparent gradients of built density and distance to downtown Edmonton, Alberta. Two urban sites occurred in constructed wetlands designed to collect and clean storm water in the city of Edmonton; Roper Pond $\left(53.4979^{\circ} \mathrm{N}, 113.4375^{\circ} \mathrm{W} ; 6.3 \mathrm{~km}\right.$ to downtown Edmonton) and Fulton Marsh (53.4813 ${ }^{\circ} \mathrm{N}, 113.3594^{\circ}$ $\mathrm{W} ; 11.5 \mathrm{~km}$ to downtown Edmonton). One suburban site was a natural wetland, Big Lake, in Lois Hole Centennial Provincial Park on the outskirts of the city of St. Albert $\left(53.6136^{\circ} \mathrm{N}\right.$, $113.6582^{\circ} \mathrm{W} ; 13.3 \mathrm{~km}$ from downtown Edmonton). The fourth site was located at the Beaverhill Lake, a provincially-protected area $\left(53.3824^{\circ} \mathrm{N}, 112.5277^{\circ} \mathrm{W} ; 67 \mathrm{~km}\right.$ from downtown Edmonton) that is the site of a long-term monitoring program for Tree Swallows (Beaverhill Bird Observatory; http://beaverhillbirds. $\mathrm{com} /$ ). Each site contained 22-50 boxes that were built following the Golondrinas design from Cornell University (http:// golondrinas.cornell.edu), erected on wooden poles, and protected from ground predators using metal sheeting. Boxes were positioned in transects around the ponds in Roper Pond and Fulton Marsh and in a grid in Big Lake and Beaverhill Lake (which was erected years previously by the staff of the Beaverhill Bird Observatory). Boxes were always positioned approximately 15-20 m apart. Boxes at Beaverhill Lake were installed prior to 2001 and some boxes at Roper Pond and Fulton Marsh were established between 2006 and 2016. We added 15 boxes at Roper Pond in 2015, 20 boxes at Fulton Marsh in 2016, and all the boxes at Big Lake in early spring 2016, augmenting an existing grid in the nearby area (installation time unknown) that was recently removed, and based on prior observations of nesting swallows in the area. As a coarse measure of water contaminants, we collected four water subsamples from each site at the end of the 2016 breeding season and pooled them by site ( $60 \mathrm{ml}$ total per site) that we sent for analyses of metals by a commercial lab (ALS Environmental Laboratory in Edmonton, AB). Water samples were collected on 9 July at Roper Pond and Fulton Marsh, 12 July at Big Lake, and 16 July at Beaverhill Lake.

\section{Bird monitoring and measurements}

Starting in May and until the breeding season ended in mid-July, we monitored clutches every third day and determined clutch initiation date by the presence of a fresh egg. Tree Swallows lay one egg per day (Winkler et al. 2011) early in the morning so we performed nest checks after $10 \mathrm{AM}$, which made it possible to assign a clutch of one to that day, a clutch of two to the previous day, and a clutch of three to the day before that. The initiation date of the first clutch in the entire study area was denoted as Study Day one in analyses (16 May). We recorded maximum clutch size and number of fledglings that left the nest. At day 12 \pm 1 day posthatch we captured breeding pairs using nest-box traps (G. Holroyd, personal communication). Both adults were banded with metal government-issued bands, weighed with a digital balance $( \pm 0.1 \mathrm{~g})$, and measured with a metallic wing ruler (headbill, wing, and tail length; $\pm 0.1 \mathrm{~mm}$ ). We collected a sample of five mantle feathers and stored them in opaque paper envelopes for subsequent color analyses. We drew a blood sample of $150 \mu$ 1 via venipuncture of the cutaneous ulnar vein. Blood was immediately placed in liquid nitrogen until permanent storage at $-80{ }^{\circ} \mathrm{C}$. Using the delayed plumage maturation of females characteristic of Tree Swallows (Hussell 1983), we classified adult females as second-year (SY) or after second-year (ASY). We did not assign males to age classes because they cannot be aged by plumage and only Beaverhill Lake had enough birds that were banded previously.

On a single day, when the oldest nestling was estimated to be 12 days old, we banded and weighed $( \pm 0.1 \mathrm{~g})$ all the chicks in the nest. We did not handle chicks at older ages because disturbing them can cause premature fledging. When handling nestlings for banding, we collected fecal sacs from defecating chicks into glass containers and pooled these by brood owing to the small mass of each individual fecal sac. We stored these samples in ice in the field and sent them to a commercial lab (ALS Environmental Laboratory in Edmonton, AB) for a finer scale, brood-specific measure of metal concentrations. We collected data from a total of 34 nest boxes, 63 adults, and 196 chicks. Number of adults does not correspond to number of boxes because in some occasions, we could not trap both adults of a box.

\section{Plumage coloration}

To measure plumage coloration quantitatively, we taped feathers onto matte black cardboard and arranged them in an overlapping fashion to approximate their usual configuration on a bird's body. We measured reflectance of these feathers using an S2000 spectrophotometer and deuterium tungsten-halogen light source (Ocean Optics, Dunedin, FL, USA). All measurements were taken with unpolarized light. We took readings using a bifurcated fibre-optic cable mounted in a metal-encased probe that transmitted incident light to the measurement area and reflected light to the spectrometer. The probe was mounted in a metal base that excluded ambient light and maintained the probe at a fixed angle perpendicular to the feather surface. Using OOIBase 32 software (Ocean Optics), we took five readings from each feather 
sample, with each reading comprising an average of 20 spectra measured sequentially. All measurements were expressed as percent reflectance relative to a Spectralon white standard (WS-1; Ocean Optics). We used the function peakshape in the R package pavo (Maia et al. 2013) to summarize our reflectance data by calculating three independent color variables that approximate three dimensions of color: hue (peak wavelength or wavelength of maximum reflectance), saturation (full width at half maximum; wavelength bandwidth of the interval of wavelengths at which the reflectance is half that at the peak), and brightness (intensity; maximum relative reflectance or reflectance at wavelength of maximum reflectance; Montgomerie 2006). We described the spectral profile of iridescent plumage at only one angle ( 90 degrees to the reading surface), but the general height of the curve for this plumage region would be expected to vary with the angle at which the feather is analyzed. Although we did not measure repeatability of our color metrics, our procedure was similar to that used in other studies (e.g., Whittingham and Dunn 2016) and no consistent bias or confound is known to result from it. We did not characterize the brown plumage of SY females because it is achromatic (Bentz and Siefferman 2013) and does not convey a sexually selected signal (Coady and Dawson 2013).

\section{Oxidative stress measurements}

To measure total glutathione (tGSH) and the ratio of reduced and oxidized glutathione (GSSG:GSH; hereafter oxidative stress) we used the DetectX Glutathione Fluorescent Detection Kit (Arbor Assays, Ann Arbor, MI, USA) following the manufacturer's protocol (K006-F1, Arbor Assays). The detection method uses ThioStar glutathione detection reagent, which is a fluorescent reagent that binds to GSH. All measurements were done in duplicate using a 96-well microplate with FLUOstar OPTIMA plate reader (BMG Labtechnologies) and two control samples were used on each plate with a detection limit of $38 \mathrm{nM}$ in the free GSH and $42 \mathrm{nM}$ in the total GSH assays.

\section{Statistical analyses}

All statistical analyses were performed in R 3. 4.3 (R Core Team 2017). Because of the relatively strong correlations among multiple measures for each of metal levels, we used principal component analyses (PCA) with oblimin rotation to produce synthetic variables for further analyses using the $\mathrm{R}$ function princomp. The original variables were first log-transformed to normalize their distributions. We used the PCA to consolidate variation among fecal samples in heavy metal concentrations of aluminum (Al), arsenic (As), cadmium $(\mathrm{Cd})$, chromium $(\mathrm{Cr})$, copper $(\mathrm{Cu})$, iron $(\mathrm{Fe})$, mercury $(\mathrm{Hg})$, lead $(\mathrm{Pb})$, antimony $(\mathrm{Sb})$, selenium $(\mathrm{Se})$, zinc $(\mathrm{Zn})$, and vanadium $(\mathrm{V})$. The PCA resulted in two components; $\mathrm{PC}_{\mathrm{MET}}$ that explained $70 \%$ of the variation and had positive loadings for $\mathrm{Al}(0.78), \mathrm{As}(0.83), \mathrm{Cr}(0.79), \mathrm{Fe}$ (0.91), Se (0.93), and V (0.76) and PC2 ${ }_{\mathrm{MET}}$ that explained $10 \%$ of the variation and had positive loadings for $\mathrm{Cu}(0.94)$ and $\mathrm{Zn}$ (0.88).

We addressed our objectives (above) by constructing linear models. Our dependent variables did not depart significantly from normality for either sex (Shapiro Wilk tests: all $\mathrm{P}>0.05$ ). Thus, we used models with Gaussian error distributions and the identity link, and we verified that the residuals for fitted models were normally distributed in every case. We evaluated model fit using an information-theoretic approach (Burnham and Anderson
2002) and standardized all variables before analysis to support interpretation of relative effect sizes and interaction estimates (Grueber et al. 2011). We compared all models (Appendix 1) using Akaike's Information Criterion corrected for small sample size (AICc).We considered models with $\triangle \mathrm{AICc}<2$ to be equivalent and averaged their coefficients, i.e., multi model inference (Harrison et al. 2018) using the R library MuMIn (Barton 2017); otherwise we identified the single best-fit model. We report standardized regression coefficients and their confidence intervals to evaluate effect sizes for predictors. Sample sizes varied among the analyses described below because data were not available for every individual and brood. We omitted from these analyses two outliers that appeared to result from measurement error or contamination; one fecal sample from Roper Pond with metal concentrations 6-times higher than the rest and one color measurement with a blueness value $53.3 \%$ above the average.

To determine whether higher concentrations of metals influenced the coloration of males and females, we constructed three groups of models; one for each color metric (hue, saturation, and brightness). For each color metric, we considered 12 candidate models that included, as explanatory variables, a combination of $\mathrm{PC} 1_{\mathrm{MET}}, \mathrm{PC} 2_{\mathrm{MET}}$, sex, and their interaction, and a model with only the intercept (Appendix 1, Table A1.1, A1.2, and A1.3 respectively for hue, saturation, and brightness). Because site was strongly correlated with the concentration of both metal principal components, it was not included in the final models. Sexes were analyzed together because preliminary analyses showed no significant differences between males and females (all $P>0.05$ ). The interactions of metals with sex were included to test whether metals influenced the color of males and females differently.

We determined whether heightened concentrations of heavy metals increased oxidative stress by constructing separate models for males and females after preliminary analyses showed that oxidative stress of males was higher than that of females (twosample $t$-test: $t_{47}=-2.43, P=0.02$ ). For females, we also ran separate models for ASY and SY females because they comprised different proportions of individuals among our four sites. For each sex and age category, we considered seven candidate models that included, as explanatory variables, a combination of $\mathrm{PC}_{\mathrm{MET}}$, $\mathrm{PC}_{\mathrm{MET}}$, and laying date, and a model with only the intercept (Appendix 1, Table A1.4).

To measure the effects of metals on the number of chicks that fledged, we used all nests that produced at least one chick $(n=$ 34). We considered 20 candidate models that included, as explanatory variables, a combination of $\mathrm{PC}_{\mathrm{MET}}, \mathrm{PC} 2_{\mathrm{MET}}$, laying date, age of the mother, and the interactions between age and metals. We included laying date because of its known influence on reproductive parameters of birds (Verhulst and Nilsson 2007), and age because of its strong influence on reproductive success in this species (Robertson and Rendell 2001; Appendix 1, Table A1.5). In addition to exploring the hypothesized causal effects of metals on each of color, oxidative stress, and number of chicks that fledged, we explored the relationship between feather color of both parents and number of chicks that fledged. To do this, we considered all pairs with an ASY female and evaluated all possible combinations of the three color metrics of each parent, with laying date and site as fixed factors. Means are presented \pm SE, unless stated otherwise. 


\section{RESULTS}

We collected data from the clutches of seven to nine pairs from each of four sites with a proportion of older (ASY) females that ranged from $63-100 \%$ (Roper Pond, seven males, seven ASY females, and two SY females; Fulton Marsh, eight males, five ASY, and three SY females; Big Lake, eight males, no ASY females, and eight SY females; Beaverhill Lake, seven males and seven ASY females). Water samples from our sites did not exhibit the metal concentrations we expected along an urban gradient. Instead, total metal concentrations were highest in the site farthest from downtown (Beaverhill Lake: $0.316 \mathrm{mg} / \mathrm{L}$ dissolved), followed by the storm water pond closest to downtown (Roper Pond: 0.189 $\mathrm{mg} / \mathrm{L}$ dissolved), followed by the suburban site (Big Lake: 0.122 $\mathrm{mg} / \mathrm{L}$ dissolved), and the more peripheral storm water pond (Fulton Marsh: $0.062 \mathrm{mg} / \mathrm{L}$ dissolved). Concentrations of all individual metals by site are provided in Appendix 2. A similar pattern of metal concentrations occurred for our finer-scale samples from chick feces, but only for $\mathrm{PC}_{\mathrm{MET}}(\mathrm{Cu}$ and $\mathrm{Zn}$; Fig. 1B); $\mathrm{PC}_{\mathrm{MET}}$ metals (Al, As, Cr, Fe, Se, and V) in chick feces increased with proximity to downtown Edmonton (Fig. 1A).

Fig. 1. Box-and-whisker plot showing outliers (circles), minimum and maximum values (whiskers), inner and outer quartile ranges (boxes), the mean (red dot), and the median value (heavy bar) of (A) $\mathrm{PC} 1_{\mathrm{MET}}$ (nonessential metals) and (B) PC2 ${ }_{\text {MET }}$ (essential metals) in feces of nestling Tree Swallows (Tachycineta bicolor) separated by site. Sample sizes are indicated over the whiskers. $\mathrm{RP}=$ Roper Pond, $\mathrm{FM}=$ Fulton Marsh, BL = Big Lake, BBO = Beaverhill Lake. Sites are presented in order of proximity to downtown Edmonton, Alberta.
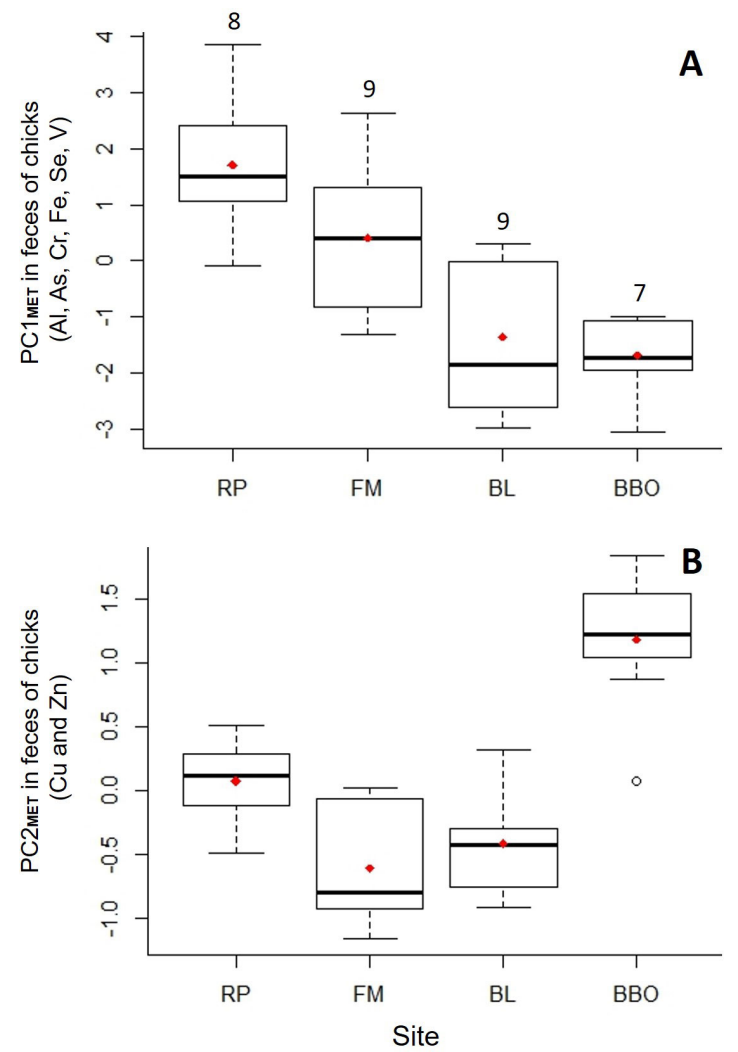

We found some support for our prediction that higher concentrations of metals, as measured in the fecal samples of chicks, would correlate with differences in feather coloration of adults. Increased concentrations of $\mathrm{PC} 2_{\mathrm{MET}}$ in chick feces, was marginally correlated with increased plumage hue (greener color; Table 1 and Fig. 2A). Concentrations of metals had no effect on saturation of feathers of adult swallows (Table 1). Greater concentrations of $\mathrm{PC} 2_{\mathrm{MET}}$ in chick feces were more strongly correlated with brightness of adult feathers (Table 1 and Fig. 2B).

Fig. 2. Relationship between (A) plumage hue and (B) plumage brightness of adult Tree Swallows (Tachycineta bicolor) and the concentration of $\mathrm{PC} 2_{\mathrm{MET}}$ in the feces of their chicks. Original data is plotted.
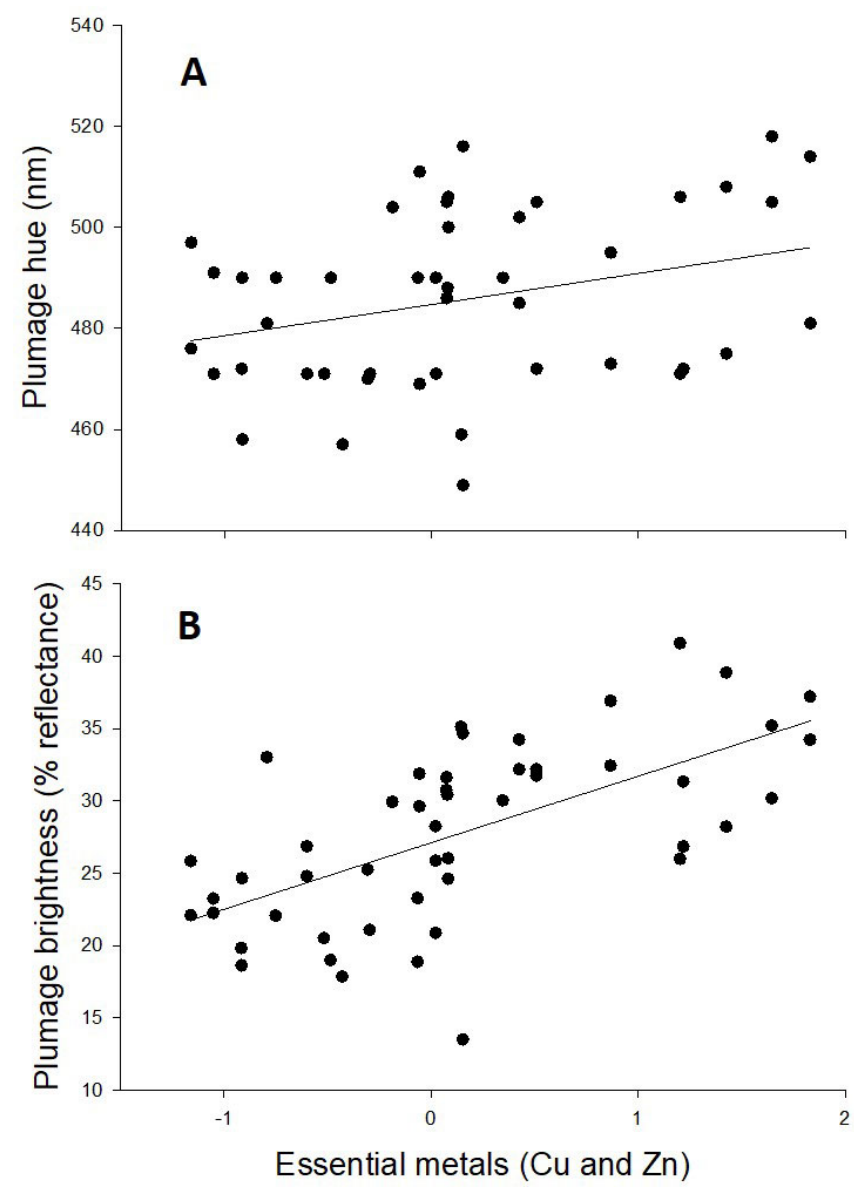

If metal pollution is detrimental to swallows, we predicted that adult birds whose chicks had higher fecal metal concentrations, would also exhibit higher levels of oxidative stress (Isaksson et al. 2005, Koivula and Eeva 2010). We found no evidence of this relationship in males, and an unexpected positive relationship in ASY females (Table 1). For males, the best-fit model showed that oxidative stress declined with advancing laying date but with confidence intervals that overlapped zero (Table 1). For ASY females, higher concentrations of $\mathrm{PC} 2 \mathrm{MET}$ were negatively correlated with oxidative stress (Table 1 and Fig. 3). For SY females, oxidative stress declined with increasing laying date, although this relationship was weak (Table 1). 
Table 1. Plumage color, oxidative stress, and number of young fledged in relation to metals in feces of Tree Swallow (Tachycineta bicolor) chicks. These model-averaged estimates were obtained from linear models. Bold predictors have $95 \%$ confidence intervals (CI) that do not include zero. SY, second year; ASY, after second year.

\begin{tabular}{|c|c|c|c|c|}
\hline Response & Model set & Predictor & Beta & $95 \% \mathrm{CI}$ \\
\hline Hue & Males and ASY females & $\begin{array}{l}\mathrm{PC} 2 \\
\text { Sex }\end{array}$ & $\begin{array}{l}5.7 \\
-8.4\end{array}$ & $\begin{array}{l}-0.01,11.42 \\
-18.21,1.41\end{array}$ \\
\hline Saturation & Males and ASY females & $\begin{array}{l}\mathrm{PC} 2{ }_{\text {MET }} \\
\mathrm{PC} 1_{\text {MET }} \\
\text { Sex }\end{array}$ & $\begin{array}{r}1.01 \\
-0.51 \\
-1.09\end{array}$ & $\begin{array}{l}-1.47,3.48 \\
-1.51,0.49 \\
-5.34,3.16\end{array}$ \\
\hline Brightness & Males and ASY females & $\begin{array}{l}\text { PC2 } \\
\text { Sex }\end{array}$ & $\begin{array}{l}4.70 \\
2.04\end{array}$ & $\begin{array}{r}\mathbf{3 . 0 0}, \mathbf{6 . 4 0} \\
-0.85,4.92\end{array}$ \\
\hline Oxidative stress & $\begin{array}{l}\text { Males } \\
\text { Females ASY } \\
\text { Females SY }\end{array}$ & $\begin{array}{l}\text { Laying date } \\
\text { PC2 } \\
\text { Laying date }\end{array}$ & $\begin{array}{c}-0.008 \\
\mathbf{- 0 . 1 3} \\
0.01\end{array}$ & $\begin{array}{l}-0.01,0.001 \\
\mathbf{- 0 . 2 2 , - 0 . 0 4} \\
-0.004,0.04\end{array}$ \\
\hline Number of young fledged & $\begin{array}{l}\text { Males and females } \\
\text { (in relation to metals) }\end{array}$ & $\mathrm{PC} 1_{\mathrm{MET}}$ & -0.19 & $-0.43,0.04$ \\
\hline Number of young fledged & $\begin{array}{l}\text { Males and ASY females } \\
\text { (in relation to colour) }\end{array}$ & $\begin{array}{l}\text { Laying date } \\
\text { Hue of male } \\
\text { Brightness of male }\end{array}$ & $\begin{array}{c}-0.65 \\
-0.64 \\
0.62\end{array}$ & $\begin{array}{l}-1.72,0.42 \\
-1.71,0.42 \\
-0.46,1.69\end{array}$ \\
\hline
\end{tabular}

Standardized coefficient estimates are given for the average of supported models within two AICc units of the best-fit model.

Fig. 3. Relationship between oxidative stress of ASY (after second year) female Tree Swallows (Tachycineta bicolor) and the concentration of $\mathrm{PC} 2_{\mathrm{MET}}$ in the feces of their chicks.

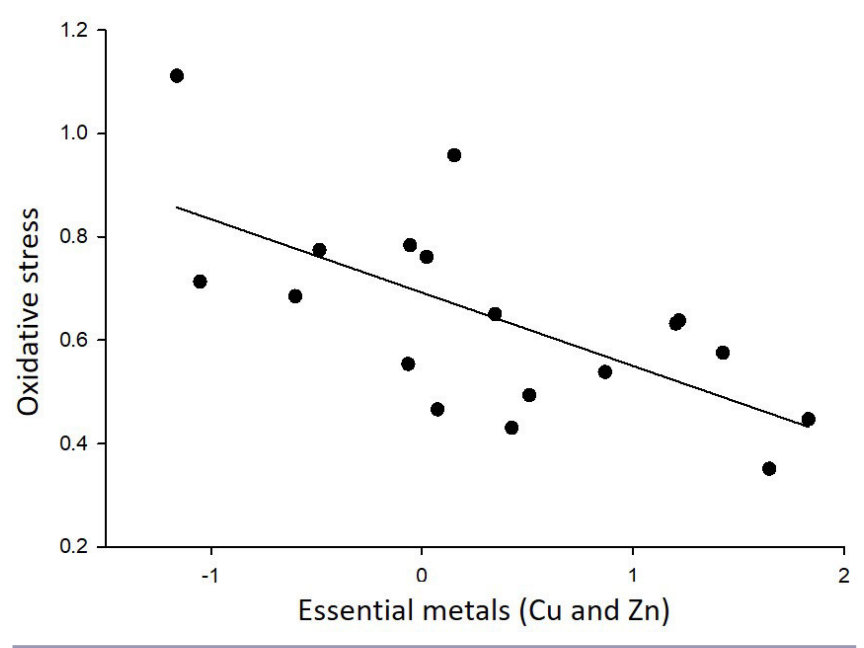

Our third objective was to determine if increased concentrations of metals reduced the reproductive success of pairs, which we measured as the number of young fledged, for all pairs that produced chicks, and did so separately for pairs with SY and ASY females. We found no effect of concentrations of metals on number of young fledged for pairs with SY females (Table 1). However, ASY females fledged fewer young when exposed to greater concentrations of $\mathrm{PCl}_{\mathrm{MET}}$, although the confidence intervals for this coefficient overlapped zero (Table 1). We found a weak negative effect of both male hue and laying date on number of young fledged, and a weak positive effect of male brightness, but all confidence intervals overlapped zero (Table 1).

\section{DISCUSSION}

In this study, we assessed the impact of environmental metals on plumage coloration, health, and reproductive success of Tree
Swallows with a goal of determining the extent to which pollution levels might be revealed noninvasively in the feather color of nesting birds. We found that in support of our predictions, ornamental color varied with metal concentrations measured in chick feces across a gradient of urban density, but the effects differed for $\mathrm{PC1}_{\mathrm{MET}}(\mathrm{Al}, \mathrm{As}, \mathrm{Cr}, \mathrm{Fe}, \mathrm{Se}$, and $\mathrm{V})$ and $\mathrm{PC} 2_{\mathrm{MET}}(\mathrm{Cu}$ and $\mathrm{Zn}$ ), and among our three color metrics (below). Contrary to our predictions, we found no evidence of an increase in oxidative stress in males exposed to more metals and the effect of $\mathrm{PC} 2_{\mathrm{MET}}$ on females was positive. As expected, there was a tendency for pairs exposed to higher concentrations of $\mathrm{PC}_{\mathrm{MET}}$ to fledge fewer young, but we found no effect of plumage coloration of males or females on the number of young fledged. These results suggest that the effects of metals on birds are complex and will require both more study and nuanced interpretation.

Our results provided limited support for the hypothesis that environmental metals alter the feather color in Tree Swallows (McGraw et al. 2002, Hill et al. 2005, Chatelain et al. 2017), but with opposing effects among our three color metrics and with only partial congruence with other studies. Whereas adult swallows whose chicks exhibited higher concentrations of $\mathrm{PC} 2_{\mathrm{MET}}$ in feces had higher values of plumage hue (a shift from bluer to greener color), they also had higher values of plumage brightness. By contrast, feral pigeons (Columba livia) that were exposed to lead, exhibited declines in both blue iridescence and brightness but only in the absence of zinc (Chatelain et al. 2017). These contrasting results suggest that relationships among various metals and iridescent coloration may act on different metrics in opposing ways (Chatelain et al. 2017).

The effects of metals on iridescent coloration may be especially difficult to determine because of the complex nanostructure of the feather barbules, which consists of keratin and melanosomes (Eliason and Shawkey 2012, Xiao et al. 2014). Variation exists in the width of the keratin cortex (Maia et al. 2011) with wider values increasing reflectance in longer wavelengths (Doucet et al. 2006), and the number and condition of barbules (Shawkey et al. 2003, Doucet et al. 2006), including tilt, influencing feather brightness 
(Van Wijk et al. 2016). Stress during feather growth, including that caused by metals, could affect both of these microstructural characteristics of feathers as well as melanin deposition in growing feathers (Griffith et al. 2006, Maia et al. 2011, Roulin 2016), which helps delimit the width of the keratin cortex (Maia et al. 2011). Furthermore, plumage coloration could be affected by feather-degrading bacteria that change the properties of the microstructure of the feathers (Shawkey et al. 2007). This might be particularly important when iridescent feathers are infected with keratinolytic bacteria, given keratin's important role in the production of iridescent color (Doucet et al. 2006). This possibility is supported by a study with pigeons that found that the presence of keratinolytic bacteria on feathers affects their brightness (Leclaire et al. 2014). Pollution can affect susceptibility to parasites in Tree Swallows (Gentes et al. 2007b), which could extend to bacteria that alter the feather structure responsible for iridescence. Thus, while iridescent feathers may be revealing of environmental metals (Chatelain et al. 2017), much work will be required to unravel the particular mechanisms and effects.

Our study assumed that the feathers of our captured birds were indicative of the conditions they experienced on the same breeding ground the previous year. This would occur if the physiological costs, stress, and metal accumulation derived from reproducing in polluted sites imposed carry-over effects that impact individuals even after the breeding season (Catry et al. 2013, Legagneux et al. 2013, Schultner et al. 2014). Such effects should apply to the costly growth of feathers (Lindström et al. 1993, Romero et al. 2005), for which the physiological cost of breeding in a polluted environment reduces the quality of feathers birds produced during the subsequent molt (DesRochers et al. 2009, Lattin et al. 2011, Maia et al. 2011). Others have shown evidence for these types of carry-over effects in male Eastern Bluebirds (Sialia sialis) that invested more in parental care by raising experimentally enlarged broods and subsequently expressed plumage color that was duller than in the year of the manipulation (Siefferman and Hill 2005). In breeding Tree Swallows, reproductive effort can reduce long-term immune function (Ardia et al. 2003). However, it is also possible that feather color is influenced by food consumed and environmental conditions at other locations, including stop-over sites during fall migration. Tree swallows in Alberta appear to leave their breeding grounds shortly after young fledge (Gow et al. 2019) and complete their molts in the American Midwest during their southward migration (Knight et al. 2018). In addition to stopover sites, birds that dispersed between breeding seasons would not have expressed exposure to metals at our capture sites. However, site fidelity in Tree Swallows appears to be very high, typically only $4-14 \%$ of breeding adults disperse to a new site (Winkler et al. 2004). We measured natal dispersal at only one of our own sites, Beaverhill Lake, where $40 \%$ of the birds we captured had previously been banded as chicks at the same site, but data was insufficient to measure breeding dispersal.

We predicted that metal exposure would impose higher levels of oxidative stress on birds, which we measured from blood samples. We were surprised that oxidative stress was unaffected by metals for males, and negatively associated for older females, because positive correlations have been reported for other bird species (Koivula and Eeva 2010, Martinez-Haro et al. 2011). One explanation for this discrepancy in our results is that PC2 ${ }_{\mathrm{MET}}$ concentrations were low enough in our study area that greater concentrations actually boosted immune function for ASY females. This possibility is supported by other studies of nestling passerines in which low metal concentrations did not cause oxidative stress (Koivula et al. 2011, Rainio et al. 2013) and by the generally low measures of oxidative stress in our study, where our values of the ratio of oxidized to free glutathione ranged from 0.3 to 2.8 , whereas a study with a positive correlation between urban pollution and oxidative stress had ratios of 2 to 4 (Isaksson et al. 2005). Another potential reason for the lacking or negative effect of metal concentration on oxidative stress in our birds is the high variation of metal types and concentrations that occurred within our sample sites, potentially obscuring the positive effects that may have occurred for some metals if they had been sampled over a more linear gradient.

In contrast to oxidative stress, the negative effect of metals we predicted was apparent in a slight decline in the number of young fledged, our measure of reproductive success, with increasing concentrations of $\mathrm{PC}_{\mathrm{MET}}$. We could not readily relate this effect of $\mathrm{PC} 1_{\mathrm{MET}}$ on reproductive success via the proxy of feather color we had hoped to reveal; color correlated only to PC2 ${ }_{\mathrm{MET}}$ (above). Nonetheless, reproductive success was not unrelated to the color of male swallows, showing a weak positive effect of brightness and a weak negative effect of hue, but with sources we cannot attribute to variation in the metals we measured. Meanwhile, the negative effect on reproductive success we found of $\mathrm{PC}_{\mathrm{MET}}$, which includes several metals of environmental concern (environmental quality guidelines for Alberta surface waters, Government of Alberta 2018), is consistent with their greater concentrations in urban areas (Lee et al. 1994, Davis et al. 2001, Wei and Yang 2010), and expected toxicological effects (e.g., Eeva et al. 2009).

The broader interpretations of our results are limited by several factors including unanticipated sources of metal pollution and the constraints of a correlative study. When we predicted metal pollution to increase with proximity to an urban center (Davis et al. 2001), partly owing to traffic volume (Wei and Yang 2010), we did not appreciate how both our suburban and rural sites were embedded in agricultural areas, which are also well-known sources of metals, including copper (Carnelo et al. 1997, Wightwick et al. 2008). We took and pooled water samples from our sites on a single day, but repeated samples might have increased our ability to associate metal concentrations to bird coloration, fecal measurements, adult health, and reproductive success. Such limitations are exacerbated for correlational studies like ours because confounding sources of variation are often unexplored. For example, we lacked information on the quality and history of birds that nested at our four sites. One example of these effects is bird age, which influences each of bird coloration (Bitton and Dawson 2008), oxidative stress (Alonso-Álvarez et al. 2009), and reproductive success (Robertson and Rendell 2001), but we had only a coarse measure of age (SY and ASY) and only for females. On the other hand, experimental studies that manipulate only one variable often contradict the results of studies in the wild (Caudill et al. 2015, Ruuskanen et al. 2015) and field-relevant work will be needed to understand how anthropogenic pollutants affect the coloration of ornamental features in wildlife (Lifshitz and St. Clair 2016). There may be particular promise in greater exploration of the nanostructure of iridescent feathers for which metal pollution may exert numerous effects. 
In summary, we showed that increased concentrations of copper and zinc, metals that were abundant in feces closer to downtown and in our rural site, slightly correlated with increased feather greenness and substantially correlated with increased brightness of adult Tree Swallows. Despite evidence that these metals correlated with swallow color, we found no support for our prediction that concentrations of metals would increase oxidative stress of adults. Although we found a slight negative relationship between metals and reproductive success, the effects of metals on color did not predict the effects of color on reproductive success. Despite its apparent complexity, we encourage more exploration of feather coloration as an early, noninvasive signal of subsequent detrimental effects of anthropogenic pollutants on bird populations (Hill 1995, Lifshitz and St. Clair 2016). In Tree Swallows, brightness may be especially revealing; brighter males are more likely to achieve extra-pair paternity (Bitton et al. 2007), which is especially prevalent in this species (Barber et al. 1996) and pairs exhibit positive assortative mating for plumage brightness (Bitton et al. 2008). Intriguingly, the metal-induced brightness we observed might cause metal-exposed birds to gain attractiveness to potential mates which, if actually detrimental, could create a signal-based evolutionary trap (sensu Schlaepfer et al.2002). Such subtle mechanisms are both tractable and worthy of study in Tree Swallows, which are among the migratory aerial insectivores that have been declining across North America since the mid-1980s (Nebel et al. 2010, Shutler et al. 2012) and may advance methods for species of even greater conservation concern.

Responses to this article can be read online at: http://www.ace-eco.org/issues/responses.php/1411

\section{Acknowledgments:}

We thank the Canadian Wildlife Service for providing a scientific banding and collection permit (10698 E), Alberta Parks for providing a scientific permit to conduct work within Lois Hole Centennial Provincial Park (16-052), and Alberta Environment and Parks for providing a Research Permit (56595) and Collection License (56596) to conduct work in Alberta. We gratefully thank many colleagues, especially Stephanie Jean and Edgar Perez for assistance with field work and Patrick Gilhooly for logistic support. We thank Geoff Holroyd and the staff of the Beaverhill Bird Observatory for access to their nest boxes and data, Jocelyn Hudon and the Royal Alberta Museum for access to their spectrophotometer, Troy Locke from MBSU (Uof A) for assistance during glutathione analysis, the City of Edmonton for access to their water quality analysis, and Alan Hingston for support during site selection. This research was supported by the Alberta Conservation Association through the ACA Grants in Biodiversity Program, a CONACyT Graduate scholarship to N. Lifshitz, and an NSERC Discovery Grant to C. C. St Clair. The study was performed under the licenses of the Animal Care \& Use Committee of the University of Alberta (No. AUP00001501).

\section{LITERATURE CITED}

Alonso-Álvarez, C., L. Pérez-Rodríguez, J. T. García, J. Viñuela, and R. Mateo. 2009. Age and breeding effort as sources of individual variability in oxidative stress markers in a bird species. Physiological and Biochemical Zoology 83:110-118. https://doi. org/10.1086/605395

Ardia, D. R., K. A. Schat, and D. W. Winkler. 2003. Reproductive effort reduces long-term immune function in breeding Tree Swallows (Tachycineta bicolor). Proceedings of the Royal Society of London B: Biological Sciences 270:1679-1683. https://doi. org/10.1098/rspb.2003.2424

Azimi, S., V. Rocher, M. Muller, R. Moilleron, and D. R. Thevenot. 2005. Sources, distribution and variability of hydrocarbons and metals in atmospheric deposition in an urban area (Paris, France). Science of the Total Environment 337:223-239. https://doi.org/10.1016/j.scitotenv.2004.06.020

Barber, C. A., R. J. Robertson, and P. T. Boag. 1996. The high frequency of extra-pair paternity in Tree Swallows is not an artifact of nestboxes. Behavioral Ecology and Sociobiology 38:425-430. https://doi.org/10.1007/s002650050260

Barton, K. 2017. MuMIn: Multi-Model Inference. R package version 1.40.0. https://CRAN.R-project.org/package=MuMIn

Bentz, A. B., and L. Siefferman. 2013. Age-dependent relationships between coloration and reproduction in a species exhibiting delayed plumage maturation in females. Journal of Avian Biology 44:80-88. https://doi.org/10.1111/j.1600-048X.2012.05730. $\mathrm{x}$

Bishop, C. A., M. D. Koster, A. A. Chek, D. J. T. Hussell, and K. Jock. 1995. Chlorinated hydrocarbons and mercury in sediments, Red-winged Blackbirds (Agelaius phoencieus) and Tree Swallows (Tachycineta bicolor) from wetlands in the Great Lakes-St. Lawrence River Basin. Environmental Toxicology and Chemistry 14:491-501. https://doi.org/10.1002/etc.5620140319

Bitton, P.-P., and R. D. Dawson. 2008. Age-related differences in plumage characteristics of male Tree Swallows Tachycineta bicolor: hue and brightness signal different aspects of individual quality. Journal of Avian Biology 39:446-452. https://doi. org/10.1111/j.0908-8857.2008.04283.x

Bitton, P.-P., R. D. Dawson, and C. L. Ochs. 2008. Plumage characteristics, reproductive investment and assortative mating in Tree Swallows Tachycineta bicolor. Behavioral Ecology and Sociobiology 62:1543-1550. https://doi.org/10.1007/s00265-008-0583-7

Bitton, P.-P., E. L. O'Brien, and R. D. Dawson. 2007. Plumage brightness and age predict extrapair fertilization success of male Tree Swallows, Tachycineta bicolor. Animal Behaviour 74:1777-1784. https://doi.org/10.1016/j.anbehav.2007.03.018

Bogden, J. D., and L. M. Klevay. 2000. Clinical nutrition of the essential trace elements and minerals. The guide for health professionals. Humana, New York, New York, USA. https://doi. org/10.1007/978-1-59259-040-7

Bókony, V., L. Z. Garamszegi, K. Hirschenhauser, and A. Liker. 2008. Testosterone and melanin-based black plumage coloration: a comparative study. Behavioral Ecology and Sociobiology 62:1229-1238. https://doi.org/10.1007/s00265-008-0551-2 
Bradl, H. B. 2005. Heavy metals in the environment: origin, interaction and remediation. Elsevier Academic, London, UK.

Brasso, R. L., and D. A. Cristol. 2008. Effects of mercury exposure on the reproductive success of Tree Swallows (Tachycineta bicolor). Ecotoxicology 17:133-141. https://doi. org/10.1007/s10646-007-0163-Z

Burger, J., and M. Gochfeld. 2004. Marine birds as sentinels of environmental pollution. EcoHealth 1:263-274. https://doi. org/10.1007/s10393-004-0096-4

Burnham, K. P., and D. R. Anderson. 2002. Model selection and multimodel inference: a practical information-theoretic approach. Second edition. Springer, New York, New York, USA.

Carnelo, L. G., S. R. de Miguez, and L. Marbán. 1997. Heavy metals input with phosphate fertilizers used in Argentina. Science of the Total Environment 204:245-250. https://doi.org/10.1016/ S0048-9697(97)00187-3

Carson R. 1962. Silent spring. First edition. Houghton Mifflin, Boston, Massachusetts, USA.

Catry, P., M. P. Dias, R. A. Phillips, and J. P. Granadeiro. 2013. Carry-over effects from breeding modulate the annual cycle of a long-distance migrant: an experimental demonstration. Ecology 94:1230-1235. https://doi.org/10.1890/12-2177.1

Caudill, M. T., E. L. Spear, C. W. Varian-Ramos, and D. A. Cristol. 2015. PHA-stimulated immune-responsiveness in mercury-dosed Zebra Finches does not match results from environmentally exposed songbirds. Bulletin of Environmental Contamination and Toxicology 94:407-411. https://doi.org/10.1007/ s00128-015-1472-1

Chatelain, M., A. Frantz, J. Gasparini, and S. Leclaire. 2016. Experimental exposure to trace metals affects plumage bacterial community in the feral pigeon. Journal of Avian Biology 47:521-529. https://doi.org/10.1111/jav.00857

Chatelain, M., A. Pessato, A. Frantz, J. Gasparini, and S. Leclaire. 2017. Do trace metals influence visual signals? Effects of trace metals on iridescent and melanic feather colouration in the feral pigeon. Oikos 126:1542-1553. https://doi.org/10.1111/oik.04262

City of St. Albert. 2012. Sturgeon River: state of the watershed report. Technical Report. City of St. Albert, Alberta, Canada

Coady, C. D., and R. D. Dawson. 2013. Subadult plumage color of female Tree Swallows (Tachycineta bicolor) reduces conspecific aggression during the breeding season. Wilson Journal of Ornithology 125:348-357. https://doi.org/10.1676/12-155.1

Crewther, W. G., R. D. B. Fraser, F. G. Lennox, and H. Lindley. 1965. The chemistry of keratins. Advances in Protein Chemistry 20:191-346. https://doi.org/10.1016/S0065-3233(08)60390-3

Cruz-Martinez, L., K. J. Fernie, C. Soos, T. Harner, F. Getachew, and J. E. G. Smits. 2015. Detoxification, endocrine, and immune responses of Tree Swallow nestlings naturally exposed to air contaminants from the Alberta oil sands. Science of the Total Environment 502:8-15. https://doi.org/10.1016/j.scitotenv.2014.09.008

Custer, C. M. 2011. Swallows as sentinel species for contaminant exposure and effect studies. Pages 45-91 in J. E. Elliott, C. A. Bishop, and C. A. Morrissey, editors. Wildlife ecotoxicology: forensic approaches. Springer, New York, New York, USA. https:// doi.org/10.1007/978-0-387-89432-4_3

Custer, C. M., T. W. Custer, C. J. Rosiu, M. J. Melancon, J. W. Bickham, and C. W. Matson. 2005. Exposure and effects of 2, 3, 7, 8-tetrachlorodibenzo-p-dioxin in Tree Swallows (Tachycineta bicolor) nesting along the Woonasquatucket River, Rhode Island, USA. Environmental Toxicology and Chemistry 24:93-109. https:// doi.org/10.1897/03-682.1

Custer, C. M., T. W. Custer, D. Warburton, D. J. Hoffman, J. W. Bickham, and C. W. Matson. 2006. Trace element concentrations and bioindicator responses in Tree Swallows from northwestern Minnesota. Environmental Monitoring and Assessment 118:247-266. https://doi.org/10.1007/s10661-006-1499-1

Dauwe, T., and M. Eens. 2008. Melanin-and carotenoiddependent signals of Great Tits (Parus major) relate differently to metal pollution. Naturwissenschaften 95:969-973. https://doi. org/10.1007/s00114-008-0400-1

Davis, A. P., M. Shokouhian, and S. Ni. 2001. Loading estimates of lead, copper, cadmium, and zinc in urban runoff from specific sources. Chemosphere 44:997-1009. https://doi.org/10.1016/ S0045-6535(00)00561-0

DesRochers, D. W., J. M. Reed, J. Awerman, J. A. Kluge, J. Wilkinson, L. I. van Griethuijsen, J. Aman, and L. M. Romero. 2009. Exogenous and endogenous corticosterone alter feather quality. Comparative Biochemistry and Physiology Part A: Molecular \& Integrative Physiology 152:46-52. https://doi. org/10.1016/j.cbpa.2008.08.034

Doucet, S. M., M. D. Shawkey, G. E. Hill, and R. Montgomerie. 2006. Iridescent plumage in satin bowerbirds: structure, mechanisms and nanostructural predictors of individual variation in colour. Journal of Experimental Biology 209:380-390. https://doi.org/10.1242/jeb.01988

Eeva, T., M. Ahola, and E. Lehikoinen. 2009. Breeding performance of Blue Tits (Cyanistes caeruleus) and Great Tits (Parus major) in a heavy metal polluted area. Environmental Pollution 157:3126-3131. https://doi.org/10.1016/j.envpol.2009.05.040

Eeva, T., E. Lehikoinen, and M. Rönkä. 1998. Air pollution fades the plumage of the Great Tit. Functional Ecology 12:607-612. https://doi.org/10.1046/j.1365-2435.1998.00221.x

Eliason, C. M., and M. D. Shawkey, 2012. A photonic heterostructure produces diverse iridescent colours in duck wing patches. Journal of the Royal Society Interface 9:2279-2289. https://doi.org/10.1098/rsif.2012.0118

Ercal, N., H. Gurer-Orhan, and N. Aykin-Burns. 2001. Toxic metals and oxidative stress part I: mechanisms involved in metalinduced oxidative damage. Current Topics in Medicinal Chemistry 1:529-539. https://doi.org/10.2174/1568026013394831

Freedman, B. 1989. Environmental ecology: the impacts of pollution and other stresses on ecosystem structure and function. Academic, San Diego, California, USA.

Geens, A., T. Dauwe, and M. Eens. 2009. Does anthropogenic metal pollution affect carotenoid colouration, antioxidative capacity and physiological condition of Great Tits (Parus major)? Comparative Biochemistry and Physiology Part C: Toxicology \& Pharmacology 150:155-163. https://doi.org/10.1016/j.cbpc.2009.04.007 
Gentes, M.-L., A. McNabb, C. Waldner, and J. E. G. Smits. $2007 a$. Increased thyroid hormone levels in Tree Swallows (Tachycineta bicolor) on reclaimed wetlands of the Athabasca oil sands. Archives of Environmental Contamination and Toxicology 53:287-292. https://doi.org/10.1007/s00244-006-0070-y

Gentes, M.-L., T. L. Whitworth, C. Waldner, H. Fenton, and J. E. Smits. 2007b. Tree Swallows (Tachycineta bicolor) nesting on wetlands impacted by oil sands mining are highly parasitized by the bird blow fly Protocalliphora spp. Journal of Wildlife Diseases 43:167-178. https://doi.org/10.7589/0090-3558-43.2.167

Giraudeau, M., A. Chavez, M. B. Toomey, and K. J. McGraw. 2015. Effects of carotenoid supplementation and oxidative challenges on physiological parameters and carotenoid-based coloration in an urbanization context. Behavioral Ecology and Sociobiology 69:957-970. https://doi.org/10.1007/s00265-015-1908$\mathrm{y}$

Gow, E. A., L. Burke, D. W. Winkler, S. M. Knight, D. W. Bradley, R. G. Clark, M. Bélisle, L. L. Berzins, T. Blake, E. S. Bridge, R. D. Dawson, P. O. Dunn, D. Garant, G. Holroyd, A. G. Horn, D. J. T. Hussell, O. Lansdorp, A. J. Laughlin, M. L. Leonard, F. Pelletier, D. Shutler, L. Siefferman, C. M. Taylor, H. Trefry, C. M. Vleck, D. Vleck, L. A. Whittingham, and D. R. Norris. 2019. A range-wide domino effect and resetting of the annual cycle in a migratory songbird. Proceedings of the Royal Society of London B: Biological Sciences 286(1894). https://doi.org/10.1098/ rspb.2018.1916

Griffith, S. C., T. H. Parker, and V. A. Olson. 2006. Melaninversus carotenoid-based sexual signals: Is the difference really so black and red? Animal Behaviour 71:749-763. https://doi. org/10.1016/j.anbehav.2005.07.016

Grueber, C. E., S. Nakagawa, R. J. Laws, and I. G. Jamieson. 2011. Multimodel inference in ecology and evolution: challenges and solutions. Journal of Evolutionary Biology 24:699-711. https://doi. org/10.1111/j.1420-9101.2010.02210.x

Hamilton, W. D., and M. Zuk. 1982. Heritable true fitness and bright birds: a role for parasites? Science 218:384-387. https://doi. org/10.1126/science.7123238

Harrison, X. A., L. Donaldson, M. E. Correa-Cano, J. Evans, D. N. Fisher, C. E. D. Goodwin, B. S. Robinson, D. J. Hodgson, and R. Inger. 2018. A brief introduction to mixed effects modelling and multi-model inference in ecology. PeerJ 6:e4794. https://doi. org/10.7717/peerj.4794

Hill, G. E. 1995. Ornamental traits as indicators of environmental health. BioScience 45:25-31. https://doi.org/10.2307/1312532

Hill, G. E., S. M. Doucet, and R. Buchholz. 2005. The effect of coccidial infection on iridescent plumage coloration in wild turkeys. Animal Behaviour 69:387-394. https://doi.org/10.1016/j. anbehav.2004.03.013

Hoffman, D. J., and G. H. Heinz. 1998. Effects of mercury and selenium on glutathione metabolism and oxidative stress in Mallard Ducks. Environmental Toxicology and Chemistry 17:161-166. https://doi.org/10.1002/etc.5620170204

Hsu, M. J., K. Selvaraj, and G. Agoramoorthy. 2006. Taiwan's industrial heavy metal pollution threatens terrestrial biota.
Environmental Pollution 143:327-334. https://doi.org/10.1016/j. envpol.2005.11.023

Hussell, D. J. 1983. Age and plumage color in female Tree Swallows. Journal of Field Ornithology 1:312-318.

Iavicoli, I., L. Fontana, and A. Bergamaschi. 2009. The effects of metals as endocrine disruptors. Journal of Toxicology and Environmental Health, Part B 12:206-223. https://doi. org/10.1080/10937400902902062

Isaksson, C., J. Örnborg, E. Stephensen, and S. Andersson. 2005. Plasma glutathione and carotenoid coloration as potential biomarkers of environmental stress in Great Tits. EcoHealth 2:138-146. https://doi.org/10.1007/s10393-005-3869-5

Jawor, J. M., and R. Breitwisch. 2003. Melanin ornaments, honesty, and sexual selection. Auk 120:249-265.

Knight, S. M., D. W. Bradley, R. G. Clark, E. A. Gow, M. Bélisle, L. L. Berzins, T. Blake, E. S. Bridge, L. Burke, R. D. Dawson, P. O. Dunn, D. Garant, G. L. Holroyd, D. J. T. Hussell, O. Lansdorp, A. J. Laughlin, M. L. Leonard, F. Pelletier, D. Shutler, L. Siefferman, C. M. Taylor, H. E. Trefry, C. M. Vleck, D. Vleck, D. W. Winkler, L. A. Whittingham, and D. R. Norris. 2018. Constructing and evaluating a continent-wide migratory songbird network across the annual cycle. Ecological Monographs 88:445-460. https://doi.org/10.1002/ecm.1298

Koivula, M. J., and T. Eeva. 2010. Metal-related oxidative stress in birds. Environmental Pollution 158:2359-2370 https://doi. org/10.1016/j.envpol.2010.03.013

Koivula, M. J., M. Kanerva, J. P. Salminen, M. Nikinmaa, and T. Eeva. 2011. Metal pollution indirectly increases oxidative stress in Great Tit (Parus major) nestlings. Environmental Research 111:362-370. https://doi.org/10.1016/j.envres.2011.01.005

Lattin, C. R., J. M. Reed, D. W. DesRochers, and L. M. Romero. 2011. Elevated corticosterone in feathers correlates with corticosterone-induced decreased feather quality: a validation study. Journal of Avian Biology 42:247-252. https://doi. org/10.1111/j.1600-048X.2010.05310.x

Lee, D. S., J. A. Garland, and A. A. Fox. 1994. Atmospheric concentrations of trace elements in urban areas of the United Kingdom. Atmospheric Environment 28:2691-2713. https://doi. org/10.1016/1352-2310(94)90442-1

Leclaire, S., P. Pierret, M. Chatelain, and J. Gasparini. 2014. Feather bacterial load affects plumage condition, iridescent color, and investment in preening in pigeons. Behavioral Ecology 25:1192-1198. https://doi.org/10.1093/beheco/aru109

Legagneux, P., N. J. Harms, G. Gauthier, O. Chastel, H. G. Gilchrist, G. Bortolotti, J. Bêty, and C. Soos. 2013. Does feather corticosterone reflect individual quality or external stress in Arctic-nesting migratory birds? PLOS ONE 8:e82644. https://doi. org/10.1371/journal.pone.0082644

Lerner, A. B. 1952. Effect of ions on melanin formation. Journal of Investigative Dermatology 18:47-52. https://doi.org/10.1038/ jid.1952.6

Lifshitz, N., and C. C. St Clair. 2016. Coloured ornamental traits could be effective and non-invasive indicators of pollution 
exposure for wildlife. Conservation Physiology 4:cow028. https:// doi.org/10.1093/conphys/cow028

Lindström, Å., G. H. Visser, and S. Daan. 1993. The energetic cost of feather synthesis is proportional to basal metabolic rate. Physiological and Biochemical Zoology 66:490-510. https://doi. org/10.1086/physzool.66.4.30163805

Maia, R., J. V. Caetano, S. N. Báo, and R. H. Macedo. 2009. Iridescent structural colour production in male Blue-black Grassquit feather barbules: the role of keratin and melanin. Journal of the Royal Society Interface 6:S203-S211. https://doi. org/10.1098/rsif.2008.0460.focus

Maia, R., C. M. Eliason, P.-P. Bitton, S. M. Doucet, and M. D. Shawkey. 2013. pavo: an R package for the analysis, visualization and organization of spectral data. Methods in Ecology and Evolution 4:906-913. https://doi.org/10.1111/2041-210x.12069

Maia, R., R. H. Macedo, and M. D. Shawkey. 2011. Nanostructural self-assembly of iridescent feather barbules through depletion attraction of melanosomes during keratinization. Journal of the Royal Society Interface 9(69). https://doi.org/10.1098/rsif.2011.0456

Martinez-Haro, M., A. J. Green, and R. Mateo. 2011. Effects of lead exposure on oxidative stress biomarkers and plasma biochemistry in waterbirds in the field. Environmental Research 111:530-538. https://doi.org/10.1016/j.envres.2011.02.012

McCarty, J. P. 2001. Use of Tree Swallows in studies of environmental stress. Reviews in Toxicology 4:61-104.

McCarty, J. P., and A. L. Secord. 2000. Possible effects of PCB contamination on female plumage color and reproductive success in Hudson River Tree Swallows. Auk 117:987-995. https://doi. org/10.2307/4089638

McGraw, K. J., E. A. Mackillop, J. Dale, and M. E. Hauber. 2002. Different colors reveal different information: how nutritional stress affects the expression of melanin-and structurally based ornamental plumage. Journal of Experimental Biology 205:3747-3755.

Meadows, M. G., T. E. Roudybush, and K. J. McGraw. 2012. Dietary protein level affects iridescent coloration in Anna's Hummingbirds, Calypte anna. Journal of Experimental Biology 215:2742-2750. https://doi.org/10.1242/jeb.069351

Mengelkoch, J. M., G. J. Niemi, and R. R. Regal. 2004. Diet of the nestling Tree Swallow. Condor 106:423-429. https://doi. org/10.1650/7341

Møller, A. P., and A. Pomiankowski. 1993. Why have birds got multiple sexual ornaments? Behavioral Ecology and Sociobiology 32:167-176. https://doi.org/10.1007/bf00173774

Montgomerie, R. 2006. Analyzing colors. Pages 90-147 in G. E. Hill and K. J. McGraw, editors. Bird coloration. Vol. 1. Mechanisms and measurements. Harvard University Press, Cambridge, Massachusetts, USA.

Nebel, S., A. Mills, J. D. McCracken, and P. D. Taylor. 2010. Declines of aerial insectivores in North America follow a geographic gradient. Avian Conservation and Ecology 5(2):1 https://doi.org/10.5751/ACE-00391-050201
Prota, G. 1993. Regulatory mechanisms of melanogenesis: beyond the tyrosinase concept. Journal of Investigative Dermatology 100:S156-S161.https://doi.org/10.1038/jid.1993.69

Prum, R. 2006. Anatomy, physics, and evolution of structural colors. Pages 295-353 in G. E. Hill and K. J. McGraw, editors. Bird coloration. Vol. 1. Mechanisms and measurements. Harvard University Press, Cambridge, Massachusetts, USA.

R Core Team. 2017. R: A language and environment for statistical computing. R Foundation for Statistical Computing, Vienna, Austria. [online] URL: https://www.R-project.org/

Rabinowitz, P. M., Z. Gordon, R. Holmes, B. Taylor, M. Wilcox, D. Chudnov, P. Nadkarni, and F. J. Dein. 2005. Animals as sentinels of human environmental health hazards: an evidencebased analysis. EcoHealth 2:26-37. https://doi.org/10.1007/ s10393-004-0151-1

Rainio, M. J., M. Kanerva, J. P. Salminen, M. Nikinmaa, and T. Eeva. 2013. Oxidative status in nestlings of three small passerine species exposed to metal pollution. Science of the Total Environment 454:466-473. https://doi.org/10.1016/j.scitotenv.2013.03.033

Robertson, R. J., and W. B. Rendell. 2001. A long-term study of reproductive performance in Tree Swallows: the influence of age and senescence on output. Journal of Animal Ecology 70:1014-1031. https://doi.org/10.1046/j.0021-8790.2001.00555.x

Romero, L. M., D. Strochlic, and J. C. Wingfield. 2005. Corticosterone inhibits feather growth: potential mechanism explaining seasonal down regulation of corticosterone during molt. Comparative Biochemistry and Physiology Part A: Molecular \& Integrative Physiology 142:65-73. https://doi. org/10.1016/j.cbpa.2005.07.014

Roulin, A. 2016. Condition-dependence, pleiotropy and the handicap principle of sexual selection in melanin-based colouration. Biological Reviews 91:328-348. https://doi. org/10.1111/brv. 12171

Roulin, A., B. Almasi, A. Rossi-Pedruzzi, A. L. Ducrest, K. Wakamatsu, I. Miksik, J. D. Blount, S. Jenni-Eiermann, and L. Jenni. 2008. Corticosterone mediates the condition-dependent component of melanin-based coloration. Animal Behaviour 75:1351-1358. https://doi.org/10.1016/j.anbehav.2007.09.007

Roux, K. E., and P. P. Marra. 2007. The presence and impact of environmental lead in passerine birds along an urban to rural land use gradient. Archives of Environmental Contamination and Toxicology 53:261-268. https://doi.org/10.1007/s00244-006-0174-4

Ruuskanen, S., T. Eeva, P. Kotitalo, J. Stauffer, and M. Rainio. 2015. No delayed behavioral and phenotypic responses to experimental early-life lead exposure in great tits (Parus major). Environmental Science and Pollution Research 22:2610-2621. https://doi.org/10.1007/s11356-014-3498-Z

Sarpong, K., C. L. Madliger, C. M. Harris, O. P. Love, S. M. Doucet, and P.-P. Bitton. 2019. Baseline corticosterone does not reflect iridescent plumage traits in female Tree Swallows. General and Comparative Endocrinology 270:123-130. https://doi. org/10.1016/j.ygcen.2018.10.015

Schlaepfer, M. A., M. C. Runge, and P. W. Sherman. 2002. Ecological and evolutionary traps. Trends in Ecology \& Evolution 17:474-480. https://doi.org/10.1016/S0169-5347(02)02580-6 
Schultner, J., B. Moe, O. Chastel, S. Tartu, C. Bech, and A. S. Kitaysky. 2014. Corticosterone mediates carry-over effects between breeding and migration in the Kittiwake Rissa tridactyla. Marine Ecology Progress Series 496:125-133. https://doi. org/10.3354/meps 10603

Shawkey, M. D., A. M. Estes, L. M. Siefferman, and, G. E. Hill. 2003. Nanostructure predicts intraspecific variation in ultraviolet-blue plumage colour. Proceedings of the Royal Society of London B: Biological Sciences 270:1455-1460. https://doi. org/10.1098/rspb.2003.2390

Shawkey, M. D., S. R. Pillai, G. E. Hill, L. M. Siefferman, and S. R. Roberts. 2007. Bacteria as an agent for change in structural plumage color: correlational and experimental evidence. American Naturalist 169:S112-S121. https://doi.org/10.1086/510100

Shutler, D., and R. G. Clark. 2003. Causes and consequences of Tree Swallow (Tachycineta bicolor) dispersal in Saskatchewan. Auk 120:619-631. https://doi.org/10.1642/0004-8038(2003)120 [0619:CACOTS]2.0.CO;2

Shutler, D., D. J. T. Hussell, D. R. Norris, D. W. Winkler, R. J. Robertson, F. Bonier, W. B. Rendell, M. Bélisle, R. G. Clark, R. D. Dawson, N. T. Wheelwright, M. P. Lombardo, P. A. Thorpe, M. A. Truan, R. Walsh, M. L. Leonard, A. G. Horn, C. M. Vleck, D. Vleck, A. P. Rose, L. A. Whittingham, P. O. Dunn, K. A. Hobson and M. T. Stanback. 2012. Spatiotemporal patterns in nest box occupancy by Tree Swallows across North America. Avian Conservation and Ecology 7(1):3. https://doi.org/10.5751/ ACE-00517-070103

Siefferman, L., and G. E. Hill. 2005. Male Eastern Bluebirds trade future ornamentation for current reproductive investment. Biology Letters 1:208-211. https://doi.org/10.1098/rsbl.2004.0274

Slominski, A., D. J. Tobin, S. Shibahara, and J. Wortsman. 2004. Melanin pigmentation in mammalian skin and its hormonal regulation. Physiological Reviews 84:1155-1228. https://doi. org/10.1152/physrev.00044.2003

Smits, J. E. G., and K. J. Fernie. 2013. Avian wildlife as sentinels of ecosystem health. Comparative Immunology, Microbiology and Infectious Diseases 36:333-342. https://doi.org/10.1016/j. cimid.2012.11.007

Snoeijs, T., T. Dauwe, R. Pinxten, F. Vandesande, and M. Eens. 2004. Heavy metal exposure affects the humoral immune response in a free-living small songbird, the Great Tit (Parus major). Archives of Environmental Contamination and Toxicology 46:399-404. https://doi.org/10.1007/s00244-003-2195-6

Stutchbury, B. J., and S. Rohwer. 1990. Molt patterns in the Tree Swallow (Tachycineta bicolor). Canadian Journal of Zoology 68:1468-1472. https://doi.org/10.1139/z90-217
Valko, M., H. Morris, and M. T. Cronin. 2005. Metals, toxicity and oxidative stress. Current Medicinal Chemistry 12:1161-1208. https://doi.org/10.2174/0929867053764635

Van Wijk, S., M. Bélisle, D. Garant and F. Pelletier. 2016. A reliable technique to quantify the individual variability of iridescent coloration in birds. Journal of Avian Biology 47:227-234. https://doi.org/10.1111/jav.00750

Vasseur, P., and C. Cossu-Leguille. 2006. Linking molecular interactions to consequent effects of persistent organic pollutants (POPs) upon populations. Chemosphere 62:1033-1042. https:// doi.org/10.1016/j.chemosphere.2005.05.043

Verhulst, S., and J.-Å Nilsson. 2007. The timing of birds' breeding seasons: a review of experiments that manipulated timing of breeding. Philosophical Transactions of the Royal Society of London B: Biological Sciences 363:399-410. https://doi. org/10.1098/rstb.2007.2146

Wei, B., and L. Yang. 2010. A review of heavy metal contaminations in urban soils, urban road dusts and agricultural soils from China. Microchemical Journal 94:99-107. https://doi. org/10.1016/j.microc.2009.09.014

White, A. E., and D. A. Cristol. 2014. Plumage coloration in Belted Kingfishers (Megaceryle alcyon) at a mercurycontaminated river. Waterbirds 37:144-152. https://doi. org/10.1675/063.037.0203

Whittingham, L. A., and P. O. Dunn. 2016. Experimental evidence that brighter males sire more extra-pair young in Tree Swallows. Molecular Ecology 25:3706-3715. https://doi.org/10.1111/ mec. 13665

Wightwick, A. M., M. R. Mollah, D. L. Partington, and G. Allinson. 2008. Copper fungicide residues in Australian vineyard soils. Journal of Agricultural and Food Chemistry 56:2457-2464. https://doi.org/10.1021/jf0727950

Winkler, D. W., K. K. Hallinger, D. R. Ardia, R. J. Robertson, B. J. Stutchbury, and R. R. Cohen. 2011. Tree Swallow (Tachycineta bicolor), version 2.0. In A. F. Poole, editor. The birds of North America online. Cornell Lab of Ornithology, Ithaca, New York, USA. https://doi.org/10.2173/bna.11

Winkler, D. W., P. H. Wrege, P. E. Allen, T. L. Kast, P. Senesac, M. F. Wasson, P. E. Llambías, V. Ferretti, and P. J. Sullivan. 2004. Breeding dispersal and philopatry in the Tree Swallow. Condor 106:768-776. https://doi.org/10.1650/7634

Xiao, M., A. Dhinojwala, and M. C. Shawkey. 2014. Nanostructural basis of rainbow-like iridescence in Common Bronzewing Phaps chalcoptera feathers. Optics Express 22:14625-14636. https://doi.org/10.1364/OE.22.014625
Editor-in-Chief: Ryan Norris Subject Editor: Dave Shutler
Sponsored by the Society of Canadian Ornithologists and Bird Studies Canada Parrainée par la Société des ornithologistes $d u$ Canada et Etudes d'oiseaux Canada

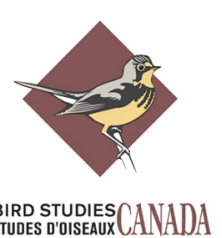


Appendix 1 - Candidate linear models of adult plumage color, oxidative stress and reproductive success in relation to concentrations of metals in feces of chicks of Tree Swallows.

\section{Table A1.1}

Candidate linear models of adult plumage hue in relation to fecal metals of Tree Swallow chicks.

\begin{tabular}{|c|c|c|c|c|}
\hline Predictors & $\log \mathrm{L}$ & $\mathrm{AICc}$ & $\triangle \mathrm{AICc}$ & wi \\
\hline $\mathrm{PC} 2_{\mathrm{MET}}+\mathrm{Sex}$ & -204.13 & 417.2 & 0.00 & 0.241 \\
\hline PC2met & -205.51 & 417.6 & 0.38 & 0.199 \\
\hline Sex & -205.97 & 418.5 & 1.30 & 0.125 \\
\hline $\mathrm{PC} 1_{\mathrm{MET}}+\mathrm{PC} 2_{\mathrm{MET}}$ & -205.14 & 419.2 & 2.02 & 0.088 \\
\hline $\mathrm{PC} 2_{\mathrm{MET}} * \operatorname{Sex}$ & -203.98 & 419.4 & 2.18 & 0.081 \\
\hline $\mathrm{PC} 1_{\mathrm{MET}} * \operatorname{Sex}+\mathrm{PC} 2_{\mathrm{MET}}$ & -202.96 & 419.9 & 2.74 & 0.061 \\
\hline Intercept only & -207.89 & 420.0 & 2.87 & 0.057 \\
\hline$P C 1_{\mathrm{MET}}+\mathrm{Sex}$ & -205.90 & 420.7 & 3.53 & 0.041 \\
\hline $\mathrm{PC} 1_{\mathrm{MET}} * \operatorname{Sex}$ & -204.72 & 420.8 & 3.67 & 0.038 \\
\hline $\mathrm{PC} 2_{\mathrm{MET}} * \mathrm{Sex}+\mathrm{PC} 1_{\mathrm{MET}}$ & -203.75 & 421.5 & 4.32 & 0.028 \\
\hline $\mathrm{PC} 1_{\mathrm{MET}}$ & -207.68 & 421.9 & 4.71 & 0.023 \\
\hline $\mathrm{PC} 1_{\mathrm{MET}} * \operatorname{Sex}+\mathrm{PC} 2_{\mathrm{MET}} * \operatorname{Sex}$ & -202.85 & 422.4 & 5.26 & 0.017 \\
\hline
\end{tabular}

$\operatorname{logL}, \log$-likelihood; AICc, size-corrected Akaike information criterion; $\triangle \mathrm{AICc}$, difference in AICc value with highest supported model; $w_{i}$, Akaike weight.

\section{Table A1.2}

Candidate linear models of adult plumage saturation in relation to fecal metals of Tree Swallow chicks.

\begin{tabular}{|c|c|c|c|c|}
\hline Predictors & $\log \mathrm{L}$ & $\mathrm{AICc}$ & $\Delta \mathrm{AICc}$ & wi \\
\hline Intercept only & -165.39 & 335.1 & 0.00 & 0.309 \\
\hline $\mathrm{PC}_{\mathrm{MET}}$ & -164.86 & 336.3 & 1.21 & 0.169 \\
\hline $\mathrm{PC} 2_{\mathrm{MET}}$ & -165.05 & 336.6 & 1.58 & 0.140 \\
\hline Sex & -165.26 & 337.0 & 1.99 & 0.114 \\
\hline $\mathrm{PC} 1_{\mathrm{MET}}+\mathrm{PC} 2_{\mathrm{MET}}$ & -164.57 & 338.0 & 3.00 & 0.069 \\
\hline $\mathrm{PC} 1_{\mathrm{MET}}+\mathrm{Sex}$ & -164.62 & 338.1 & 3.10 & 0.066 \\
\hline $\mathrm{PC} 2_{\mathrm{MET}}+\mathrm{Sex}$ & -164.97 & 338.9 & 3.81 & 0.046 \\
\hline $\mathrm{PC} 1_{\mathrm{MET}} * \mathrm{Sex}$ & -163.89 & 339.2 & 4.12 & 0.039 \\
\hline $\mathrm{PC} 2_{\mathrm{MET}} * \mathrm{Sex}$ & -164.45 & 340.3 & 5.25 & 0.022 \\
\hline $\mathrm{PC} 1_{\mathrm{MET}} * \mathrm{SeX}+\mathrm{PC} 2_{\mathrm{MET}}$ & -163.74 & 341.5 & 6.43 & 0.012 \\
\hline $\mathrm{PC} 2_{\mathrm{MET}} * \operatorname{Sex}+\mathrm{PC} 1_{\mathrm{MET}}$ & -163.99 & 342.0 & 6.95 & 0.010 \\
\hline $\mathrm{PC} 1_{\mathrm{MET}} * \operatorname{Sex}+\mathrm{PC} 2_{\mathrm{MET}} * \operatorname{Sex}$ & -163.44 & 343.6 & 8.56 & 0.004 \\
\hline
\end{tabular}

$\operatorname{logL}, \log$-likelihood; AICc, size-corrected Akaike information criterion; $\triangle \mathrm{AICc}$, difference in AICc value with highest supported model; $w_{i}$, Akaike weight. 
Table A1.3

Candidate linear models of adult plumage brightness in relation to fecal metals of Tree Swallow chicks.

\begin{tabular}{|c|c|c|c|c|}
\hline Predictors & $\log \mathrm{L}$ & $\mathrm{AICc}$ & $\Delta \mathrm{AICc}$ & wi \\
\hline $\mathrm{PC} 2_{\mathrm{MET}}$ & -145.99 & 298.5 & 0.00 & 0.350 \\
\hline $\mathrm{PC} 2_{\mathrm{MET}}+\mathrm{Sex}$ & -144.94 & 298.8 & 0.27 & 0.306 \\
\hline $\mathrm{PC} 1_{\mathrm{MET}}+\mathrm{PC} 2_{\mathrm{MET}}$ & -145.96 & 300.8 & 2.32 & 0.110 \\
\hline $\mathrm{PC} 2_{\mathrm{MET}} *$ Sex & -144.77 & 300.9 & 2.43 & 0.104 \\
\hline $\mathrm{PC} 1_{\mathrm{MET}} * \operatorname{Sex}+\mathrm{PC} 2_{\mathrm{MET}}$ & -143.79 & 301.6 & 3.08 & 0.075 \\
\hline $\mathrm{PC} 2_{\mathrm{MET}} * \operatorname{Sex}+\mathrm{PC} 1_{\mathrm{MET}}$ & -144.68 & 303.4 & 4.86 & 0.031 \\
\hline $\mathrm{PC} 1_{\mathrm{MET}} * \mathrm{Sex}+\mathrm{PC} 2_{\mathrm{MET}} * \mathrm{Sex}$ & -143.54 & 303.8 & 5.31 & 0.025 \\
\hline Intercept only & -158.18 & 320.6 & 22.11 & 0.000 \\
\hline Sex & -158.13 & 322.8 & 24.29 & 0.000 \\
\hline $\mathrm{PC} 1_{\mathrm{MET}}$ & -158.17 & 322.9 & 24.36 & 0.000 \\
\hline $\mathrm{PC}_{\mathrm{MET}}+\mathrm{Sex}$ & -158.13 & 325.2 & 26.65 & 0.000 \\
\hline $\mathrm{PC} 1_{\mathrm{MET}} *$ Sex & -156.97 & 325.3 & 26.84 & 0.000 \\
\hline
\end{tabular}

$\operatorname{logL}, \log$-likelihood; AICc, size-corrected Akaike information criterion; $\triangle \mathrm{AICc}$, difference in AICc value with highest supported model; $w_{i}$, Akaike weight.

\section{Table A1.4}

Candidate linear models of oxidative stress of adult males, ASY females and SY females in relation to fecal metals of Tree Swallow chicks.

\begin{tabular}{|c|c|c|c|c|}
\hline Predictors & $\log L$ & $\mathrm{AICc}$ & $\triangle \mathrm{AICc}$ & wi \\
\hline \multicolumn{5}{|l|}{ Males } \\
\hline LDATE & 25.54 & -44.0 & 0.00 & 0.35 \\
\hline Intercept only & 23.90 & -43.3 & 0.73 & 0.24 \\
\hline $\mathrm{PC} 1_{\mathrm{MET}}+\mathrm{LDATE}$ & 25.83 & -41.0 & 2.19 & 0.12 \\
\hline $\mathrm{PC} 1_{\mathrm{MET}}$ & 24.33 & -41.6 & 2.41 & 0.10 \\
\hline $\mathrm{PC} 2_{\mathrm{MET}}+\mathrm{LDATE}$ & 25.56 & -41.3 & 2.74 & 0.09 \\
\hline $\mathrm{PC} 2_{\mathrm{MET}}$ & 23.95 & -40.9 & 3.17 & 0.07 \\
\hline $\mathrm{PC} 1_{\mathrm{MET}}+\mathrm{PC} 2_{\mathrm{MET}}$ & 24.38 & -38.9 & 5.10 & 0.03 \\
\hline \multicolumn{5}{|l|}{ ASY Females } \\
\hline $\mathrm{PC} 2_{\mathrm{MET}}$ & 9.77 & -11.8 & 0.00 & 0.45 \\
\hline $\mathrm{PC} 2_{\mathrm{MET}}+\mathrm{LDATE}$ & 11.30 & -11.5 & 0.30 & 0.39 \\
\hline $\mathrm{PC} 1_{\mathrm{MET}}+\mathrm{PC} 2_{\mathrm{MET}}$ & 9.78 & -8.5 & 3.34 & 0.08 \\
\hline LDATE & 7.63 & -7.5 & 4.28 & 0.05 \\
\hline Intercept only & 4.74 & -4.7 & 7.14 & 0.01 \\
\hline $\mathrm{PC}_{\mathrm{MET}}+$ LDATE & 7.65 & -4.2 & 7.59 & 0.01 \\
\hline $\mathrm{PC} 1_{\mathrm{MET}}$ & 4.99 & -2.3 & 9.55 & 0.00 \\
\hline \multicolumn{5}{|l|}{ SY females } \\
\hline LDATE & 8.37 & -8.1 & 0.00 & 0.39 \\
\hline Intercept only & 6.09 & -7.0 & 1.09 & 0.23 \\
\hline
\end{tabular}




\begin{tabular}{|c|c|c|c|c|}
\hline $\mathrm{PC} 1_{\mathrm{MET}}$ & 7.40 & -6.1 & 1.93 & 0.15 \\
\hline $\mathrm{PC}_{\mathrm{MET}}+\mathrm{LDATE}$ & 9.03 & -5.1 & 3.01 & 0.09 \\
\hline PC $2_{\text {MET }}+$ LDATE & 8.76 & -4.5 & 3.55 & 0.07 \\
\hline PC2 $2_{\mathrm{MET}}$ & 6.11 & -3.6 & 4.52 & 0.04 \\
\hline $\mathrm{PC} 1_{\mathrm{MET}}+\mathrm{PC} 2_{\mathrm{MET}}$ & 8.07 & -3.2 & 4.92 & 0.03 \\
\hline
\end{tabular}

$\log \mathrm{L}, \log$-likelihood; AICc, size-corrected Akaike information criterion; $\triangle \mathrm{AICc}$, difference in AICc value with highest supported model; $w_{i}$, Akaike weight; LDATE, laying date.

\section{Table A1.5}

Candidate linear models of number of young fledged in relation to fecal metals of Tree Swallow chicks.

\begin{tabular}{|c|c|c|c|c|}
\hline Predictors & $\log L$ & $\mathrm{AICc}$ & $\triangle \mathrm{AICc}$ & wi \\
\hline $\mathrm{PC}_{\mathrm{MET}}$ & -46.00 & 98.9 & 0.00 & 0.33 \\
\hline $\mathrm{PC} 1_{\mathrm{MET}}+\mathrm{AGEf}$ & -45.88 & 101.3 & 2.42 & 0.09 \\
\hline $\mathrm{PC} 1_{\mathrm{MET}}+\mathrm{PC} 2_{\mathrm{MET}}$ & -45.98 & 101.5 & 2.61 & 0.09 \\
\hline $\mathrm{PC} 1_{\mathrm{MET}}+\mathrm{LDATE}$ & -46.00 & 101.5 & 2.65 & 0.09 \\
\hline AGEf & -47.39 & 101.7 & 2.78 & 0.08 \\
\hline $\mathrm{PC} 2_{\mathrm{MET}}$ & -47.42 & 101.7 & 2.85 & 0.08 \\
\hline LDATE & -47.42 & 101.7 & 2.85 & 0.08 \\
\hline $\mathrm{PC} 2_{\mathrm{MET}} *$ AGEf & -45.75 & 103.9 & 5.02 & 0.03 \\
\hline $\mathrm{PC} 1_{\mathrm{MET}} *$ AGEf & -45.82 & 104.0 & 5.15 & 0.02 \\
\hline $\mathrm{PC} 2_{\mathrm{MET}}+\mathrm{AGEf}$ & -47.36 & 104.3 & 5.37 & 0.02 \\
\hline LDATE + AGEf & -47.39 & 104.3 & 5.43 & 0.02 \\
\hline PC $2_{\mathrm{MET}}+$ LDATE & -47.42 & 104.4 & 5.49 & 0.02 \\
\hline $\mathrm{PC} 2_{\mathrm{MET}} * \mathrm{AGEf}+\mathrm{PC} 1_{\mathrm{MET}}$ & -44.93 & 105.4 & 6.46 & 0.01 \\
\hline $\mathrm{PC} 2_{\mathrm{MET}} * \mathrm{AGEf}+\mathrm{LDATE}$ & -45.73 & 107.0 & 8.08 & 0.00 \\
\hline $\mathrm{PC} 1_{\mathrm{MET}} * \mathrm{AGEf}+\mathrm{PC} 2_{\mathrm{MET}}$ & -45.74 & 107.0 & 8.09 & 0.00 \\
\hline $\mathrm{PC}_{\mathrm{MET}} *$ AGEf + LDATE & -45.82 & 107.1 & 8.25 & 0.00 \\
\hline $\mathrm{PC} 1_{\mathrm{MET}} * \mathrm{AGEf}+\mathrm{PC} 2_{\mathrm{MET}} * \mathrm{AGEf}$ & -44.90 & 108.7 & 9.79 & 0.00 \\
\hline $\mathrm{PC} 2_{\mathrm{MET}} * \mathrm{AGEf}+\mathrm{PC} 1_{\mathrm{MET}}+\mathrm{LDATE}$ & -44.91 & 108.7 & 9.81 & 0.00 \\
\hline $\mathrm{PC} 1_{\mathrm{MET}} * \mathrm{AGEf}+\mathrm{PC} 2_{\mathrm{MET}}+\mathrm{LDATE}$ & -45.73 & 110.3 & 11.45 & 0.00 \\
\hline $\mathrm{PC} 1_{\mathrm{MET}} * \mathrm{AGEf}+\mathrm{PC} 2_{\mathrm{MET}} *$ AGEf + LDATE & -44.90 & 112.3 & 13.45 & 0.00 \\
\hline
\end{tabular}

$\log \mathrm{L}, \log$-likelihood; AICc, size-corrected Akaike information criterion; $\triangle \mathrm{AICc}$, difference in AICc value with highest supported model; $w_{i}$, Akaike weight; LDATE, laying date; AGEf, age of the female. 
Appendix 2 - Single-sample water concentrations of metals from our 4 sites. On the same day, we collected 4 samples on different locations of each site and pooled them for analysis to produce the single measures listed here. Sites are presented in order of proximity to downtown Edmonton.

\section{Table A2.1}

Single-sample water concentrations of metals from our 4 sites.

\begin{tabular}{|c|c|c|c|c|c|c|c|c|c|c|c|c|c|c|c|}
\hline SITE & $\mathrm{Al}$ & $\mathrm{Sb}$ & As & $\mathrm{Cd}$ & $\mathrm{Cr}$ & $\mathrm{Cu}$ & $\mathrm{Fe}$ & $\mathrm{Pb}$ & $\mathrm{MeHg}$ & $\mathrm{Se}$ & $\mathrm{Zn}$ & V & $\sum$ metals & PC1met & PC2met \\
\hline $\mathrm{RP}$ & 0.0048 & 00019 & 0.00242 & 0.000005 & 0.0002 & 0.00144 & 0.175 & 0.000063 & 0.000491 & 0.000145 & 0.0051 & 0.00067 & 0.185 & 0.183235 & 654 \\
\hline FM & 0062 & 0.00025 & 0.00284 & 0.000005 & 0.00017 & 0.00196 & 049 & .00005 & 0.000489 & 000242 & 0.001 & 0.00099 & 206 & 42 & 0.00296 \\
\hline BL & 0.0028 & 0.00013 & 0.00178 & 0.000005 & 0.00013 & 0.00141 & 0.114 & 0.00005 & 0.000691 & 0.000109 & 0.002 & 0.0005 & 0.123105 & 0.119319 & 0.00341 \\
\hline BBO & 0.0955 & 0.0005 & 0.0024 & 0.000182 & 0.00056 & 0.0043 & 0.191 & 0.00025 & 0.00638 & 0.00025 & 0.02 & 0.0025 & 0.321322 & 0.29221 & 0.0243 \\
\hline
\end{tabular}

RP; Roper Pond, FM; Fulton Marsh, BL; Big Lake, BBO; Beaverhill Lake, Al; aluminum, Sb; antimony, As; arsenic, Cd; cadmium, Cr; chromium, $\mathrm{Cu}$; copper, Fe; iron, $\mathrm{Pb}$; lead, MeHg; methylmercury, Se; selenium, Zn; zinc, V; vanadium, $\sum$ metals; sum of all metals, PC1met; sum of metals included in the PC1 of fecal metals ( $\mathrm{Al}, \mathrm{As}, \mathrm{Cr}, \mathrm{Fe}, \mathrm{Se}, \mathrm{V}), \mathrm{PC} 2 \mathrm{met}$; sum of metals included in the PC2 of fecal metals $(\mathrm{Cu}$ and $\mathrm{Zn})$. 